\title{
Whither Japan's Heisei reforms? A systems approach to analysing legal changes in Japan
}

\author{
SARAH XIN YI CHUA
}

\section{Abstract}

A wave of legal reforms since the 1990s, known collectively as the 'Heisei reforms', has sparked lively debate about whether Japan is at a turning point. Indeed, the task of understanding the fitful and ambiguous pathways of normative and behavioural change that followed remains a Herculean one. Rather than confining these irreducibly diverse phenomena to simplistic but ultimately uninformative theoretical abstractions, this paper adopts a systems approach which locates its analysis in the complex dynamics which underpin the Heisei reforms and provides an analytical framework to explore the multifaceted processes of change that have accompanied the reforms in practice. In this way, a systems approach offers a richer methodology to evaluating the reforms' effectiveness in generating desired change. By applying this approach to case studies in information disclosure, corporate governance and gender equality reforms, this paper argues that the Heisei reforms have reshaped political, economic and social dimensions of Japanese society in ways that other approaches may have overlooked. While the reforms have appeared evolutionary rather than revolutionary, they have nevertheless laid the foundations for potentially transformative change in the long term by starting to challenge the established societal norms and discourses that mediate law and legal change in Japan.

\section{Introduction}

With its time-honoured history of incorporating external legal influences, Japan's legal system has been dubbed a 'paradox' that interweaves the antinomies of continuity and change. ${ }^{1}$ Major legal reforms in Japan since the 1990s, known collectively as the Heisei reforms, have been touted as another

1 John Owen Haley, Authority without Power (Oxford University Press, 1991) 3. 
key turning point in its legal landscape. ${ }^{2}$ As the magnitude of change fails to fulfil expectations over time, doubts about the effectiveness of the reforms begin to fester. For some, the basic structures of Japanese society remain 'untouched' by the Heisei reforms, portending merely a superficial rather than a profound change. ${ }^{3}$ For others, the Heisei reforms retain considerable promise by having initiated a gradual but momentous shift in mindsets. ${ }^{4}$ Ultimately, the diverse and often inconsistent trajectories of change that have occurred across Japanese society severely hamper efforts to generalise on the Heisei reforms' overall success. ${ }^{5}$ Instead, by considering how law and society intertwine in discourse to shape the normative agendas of the Heisei reforms, systems theory appreciates the complex dynamics underpinning legal change and thus offers a richer evaluation of their effectiveness.

This paper first examines the Heisei reforms' development as a legal project. Next, it outlines systems theory and demonstrates its strengths as a methodology for evaluating legal reform in Japan. Using this systems approach, this paper then examines the case studies of information disclosure, corporate governance and gender equality. This provides for an evaluation of the Heisei reforms as a composite picture of interrelated political, economic and social dynamics. Altogether, these case studies demonstrate that the Heisei reforms represent an attempt to fundamentally reshape aspects of Japanese society. Their success, however, has been mitigated and influenced by a range of political, economic and social factors beyond the control of law-makers in Japan. Finally, drawing on the dynamics of reform from all three case studies, this paper demonstrates that, by reshaping the societal norms and discourses underlying legal changes in Japan, the Heisei reforms have nevertheless laid the foundations for potentially transformative change in the long term.

\section{Japan's Heisei reforms: A background}

Initially designed as cohesive strategies to reinvent Japan in a period of profound political, economic and social change, ${ }^{6}$ the Heisei reforms have evolved into an eclectic mix of ad hoc efforts to mediate the diverse interests at stake. The complex

\footnotetext{
2 See e.g. Kent Anderson and Trevor Ryan, 'Japan: The Importance and Evolution of Legal Institutions at the Turn of the Century' in E. Ann Black and Gary F. Bell (eds), Law and Legal Institutions of Asia (Cambridge University Press, 2011) 120, 125.

3 John O. Haley, 'Heisei Renewal or Heisei Transformation: Are Legal Reforms Really Changing Japan?' (Working Paper No. 05-10-02, The Washington University School of Law, October 2002) 7.

4 See e.g. Jeff Kingston, Japan's Quiet Transformation (Routledge Curzon, 2004) 306-311.

5 Souichirou Kozuka, 'Conclusions: Japan's Largest Companies, Then and Now' in Luke Nottage, Leon Wolff and Kent Anderson (eds), Corporate Governance in the 21st Century (Edward Elgar, 2008) 228, 245.

6 See e.g. Gerald Paul McAlinn, 'Law Reform in Japan,: Building Infrastructure for the 21st Century' in Kenneth L. Port and Gerald Paul McAlinn (eds), Comparative Law: Law and the Legal Process in Japan (Carolina Academic Press, 2nd ed., 2003) 113, 113.
} 
and disparate ways in which the Heisei reforms were unleashed occurred against an interplay of internal crises and external pressures for change, generating imperatives to reform all levels of society: reinvent the Japanese government's credibility, overcome economic mismanagement, and improve gender relations to maintain a viable social order. ${ }^{7}$ Through it all, to minimise the dislocations across Japanese society that could come with abrupt change, the dynamics of reform also had to temper wide-ranging change with a degree of continuity. ${ }^{8}$ Moreover, despite a general recognition of the need for change in Japan, there were marked disagreements on its execution including among vested interests who sought to preserve their advantages and strengthening voices of diverse groups seeking reform in specific directions. ${ }^{9}$ Accordingly, pathways for reform had to be carefully calibrated and continuously revised to manage tensions among competing interests during a transitional period where new practices and institutions were to emerge alongside a discredited regime. ${ }^{10}$ Therefore, from the start, the multifaceted and sometimes conflicting imperatives for change augured fitful and incremental, yet potentially transformative, processes of reform in the coming decades.

\section{Theoretical framework}

In evaluating the Heisei reforms, systems theory provides the nuance appropriate to an analysis of the multifaceted processes of change that have accompanied the legal reforms in practice. Systems theory argues that legal reforms are conceived and integrated in society through communication by human agents. ${ }^{11}$ Here, the concept of legal reforms not only comprises a state's legal instruments such as legislation and doctrines but also broader guidelines of behaviour such as tacitly accepted social norms. ${ }^{12}$ Accordingly, discourse among human agents can occur in multiple ways, including formal and informal spoken interaction or written texts, and through multiple dimensions, especially political, economic, moral and legal modes of communication. ${ }^{13}$ On the one hand, society uses internal frames of reference that exist to understand and communicate changes in considering possibilities for legal reform, ${ }^{14}$ creating their own reality and

7 Kingston, Japan's Quiet Transformation, above n 4, 2-4, 12, 257.

8 See e.g. Takao Tanase, Community and the Law: A Critical Reassessment of American Liberalism and Japanese Modernity (Edward Elgar, 2010) 11.

9 Kingston, Japan's Quiet Transformation, above n 4, 3-4.

10 Ibid., 310-11.

11 Tanase, above n 8, 156; John Gillespie, 'Towards a Discursive Analysis of Legal Transfers into Developing East Asia' (2008) 40 International Law and Politics 657, 661.

12 See e.g. Michael King, “The "Truth" About Autopoiesis' (1993) 20(2) Journal of Law and Society 220.

13 Gillespie, above $\mathrm{n} 11,683$.

14 See e.g. Anthony Beck, 'Is Law an Autopoietic System?' (1994) 14 Oxford Journal of Legal Studies 401, 404-15. 
meanings from new ideas and practices. ${ }^{15}$ On the other hand, legal reforms influence local thinking by shaping contingent understandings and practices in society. ${ }^{16}$ These discursive processes of interpretation, selection, adaptation and implementation of legal reforms 'unleashes an evolutionary dynamic', ${ }^{17}$ where society is reconfigured in adapting to different models of regulation as much as newly introduced rules are modified through their application and integration into society. ${ }^{18}$

The benefits of this approach in evaluating Japan's Heisei reforms are twofold. Firstly, systems theory conceives legal reforms as communicative events that are socially constructed and thus inherently subjective. ${ }^{19}$ Accordingly, it avoids conceptual problems of assessing the reforms' effectiveness against broad essentialist standards such as 'justice' and 'rule of law', ${ }^{20}$ which tend to presuppose objectivity where no such objectivity in fact exists. Secondly, by locating communication in the recipient country's empirical context of political, economic and social structures, ${ }^{21}$ this framework facilitates a multiparametric analysis that considers the diverse elements underlying the Heisei reforms in Japanese society. Altogether, this allows theory to trace in a more precise fashion the complex and multifaceted connection between the Heisei reforms and Japanese society in practice.

Based on systems theory, a two-step methodology can be formulated to evaluate the Heisei reforms' effectiveness. Under this framework, where there is communicative interaction about possible legal changes in a society, a normative agenda is discursively constructed within a context of longstanding beliefs and practices. ${ }^{22}$ This normative agenda reflects the influences of a range of stakeholders and is realised through enacting legal reforms. ${ }^{23}$ Accordingly, in considering the normative agenda that has been created through this process, the first step assesses the extent to which the Heisei reforms have reflected a significant transformation of Japanese society. Next, the second step evaluates how much behavioural change has occurred according to the normative agenda arrived at in the first step. Therefore, it is against these two criteria of normative and behavioural change that has occurred from the Heisei reforms' institution that this paper evaluates their strengths and weaknesses.

15 See e.g. Niklas Luhmann, 'The Unity of the Legal System' in Gunther Teubner (ed.), Autopoietic Law:

A New Approach to law and society (De Gruyter,1988) 12, 21-35.

16 Gillespie, above n 11, 681.

17 Ibid., 680.

18 Tanase, above n 8, ix; Gillespie, above $\mathrm{n} 11,681$.

19 Gillespie, above $\mathrm{n} 11,719$.

20 Ibid.

21 Ibid.

22 Ibid., 720

23 Ibid. 


\section{Evaluation}

\section{Information disclosure reforms}

While in truth a reflection of normative change that had already occurred at the level of local government, the national information disclosure laws ultimately enacted in the 1990s nevertheless symbolise a fundamental reshaping of citizen-state relations in Japan. Despite the bureaucracy's recognition that responsibilities to perform its functions competently flowed from the strong and privileged position that it had long occupied in Japanese society and of the consequences for Japanese citizens of their decisions, it did not regard its relationship with citizens to entail a concomitant normative duty of 'accountability' to explain its actions. ${ }^{24}$ For their part, citizens regarded the bureaucracy with a 'mixture of fear and reverence'. ${ }^{25}$ While longstanding Liberal Democratic Party (LDP) governments were seen as uninterested in adopting a national law requiring information disclosure to citizens, ${ }^{26}$ the eventual enactment of the Administrative Information Disclosure Act 1999 (the AIDA) reflected the significant normative change that had already been achieved at the local government level. Although terms including 'transparency' and 'accountability' had barely entered into mainstream discourse before, ${ }^{27}$ these concepts gained increasing credence across Japanese society as more progressive local governments exercised their constitutional autonomy from the national government and sought to incorporate disclosure reforms in their jurisdiction. ${ }^{28}$ Likewise, the use of these newly created legal avenues to expose public officials' misuse of public funds have been credited with further increasing public awareness and support for information disclosure reforms. ${ }^{29}$ Whether or not Repeta can rightly claim a 'national consensus' in favour of information disclosure reform by the early $1980 \mathrm{~s}^{30}$ it is nevertheless true that a substantial change in the normative agenda in relation to information disclosure had occurred by the time of the 1999 Heisei reforms. By then, each prefecture had initiated disclosure guidelines or ordinances. ${ }^{31}$ Thus, when the national government conceded in

\footnotetext{
24 Narifumi Kadomatsu, 'Accountability of Administration in Japan after the Mid-1990s' (2011) 31 Journal of Japanese Law 5, 5-6.

25 Kingston, Japan's Quiet Transformation, above n 4, 46.

26 David Boling, Access to Government-Held Information in Japan: Citizens' “Right to Know” Bows to the Bureaucracy' (1998) 34 Stanford Journal of International Law 1, 19-20.

27 Katsuya Uga, 'Development of the Concepts of Transparency, and Accountability in Japanese Administrative Law' in Daniel H Foote (ed.), Law in Japan: A Turning Point (University of Washington Press, 2007) 276, 277; Kadomatsu, Accountability of Administration in Japan, above n 24, 5-6.

28 Lawrence Repeta, 'Local Government Disclosure Systems in Japan' (Working Paper No. 16, The National Bureau of Asian Research, October 1999) 5-6; Kingston, Japan's Quiet Transformation, above n 4, 46, 52.

29 Kingston, Japan's Quiet Transformation, above n 4, 46.

30 See Repeta, 'Local Government Disclosure Systems in Japan', above n 28, 4.

31 Ibid., 6.
} 
1999 the need for government to respond to all information disclosure requests, this symbolised the national government's acceptance of the changed normative agenda in citizen-state relations. ${ }^{32}$ Article 1 of the AIDA, for example, stated its perceived necessity in 'ensuring that government fulfils its duty to explain its various operations to the people and contributing to the promotion of a fair and democratic administration subject to the proper understanding and criticism of the people'. ${ }^{33}$ Therefore, while the Heisei reforms in favour of information disclosure can more accurately be said to have mirrored a marked social transformation rather than having been the cause of this change, they undoubtedly reposition the bureaucracy in Japanese society.

However, while these reforms seek to reshape Japan's citizen-state relations, the extent of behavioural change towards disclosure has been limited due to institutional dynamics and the bureaucracy's reluctance to relinquish its historically privileged position in Japanese society. While some have suggested that the bureaucracy's control over staffing decisions of the Supreme Court may be responsible for the latter's general reluctance to rule in favour of information disclosure, ${ }^{34}$ their willingness to overrule lower court decisions excepting governments from disclosure requirements at best demonstrate that judicial attitudes have been mixed. ${ }^{35}$ By contrast, the bureaucracy's response to the reforms has been less surprising. Reflecting Kingston's observation that 'old habits cannot be abruptly reversed by legal fiat', ${ }^{36}$ the bureaucracy has resisted the adaptation to a relationship of accountability to citizens. ${ }^{37}$ Here, the bureaucracy has been accused of inefficiently handling disclosure requests and having engaged in a 'time-consuming process of weeding out "inconvenient" documents' prior to the law's commencement. ${ }^{38}$ Likewise, Boling's suspicion that the 'bureaucracy's law-drafting monopoly' would result in 'ambiguous' legislative terms allowing bureaucrats continuing discretion has been vindicated. ${ }^{39}$ The law, as it is drafted, provides for access to 'documents held by the administration', and denies recourse to require disclosure where a document containing certain information has not been generated or has already been disposed of. ${ }^{40}$ Therefore, while the requirement to put in place procedures

\footnotetext{
32 See e.g. Kingston, Japan's Quiet Transformation, above n 4, 52, 56.

33 See Lawrence Repeta, 'Special Note: “Freedom" of Information?' in Kenneth L Port and Gerald Paul McAlinn (eds), Comparative Law: Law and the Legal Process in Japan (Carolina Academic Press, 2nd ed., 2003) $1021,1021$.

34 See e.g. David Law, 'Why Has Judicial Review Failed in Japan?' (2011) 88 Washington University Law Review 1425, 1462-3.

35 Jeff Kingston, Contemporary Japan: History, Politics, and Social Change since the 1980s (Wiley Blackwell, 2nd ed., 2013) 32-33.

36 Kingston, Japan's Quiet Transformation, above n 4, 48, 54.

37 Ibid., 48, 54.

38 Ibid., 53, 56.

39 Boling, above n 26, 20, 37; see also Kingston, Japan's Quiet Transformation, above n 4, 54.

40 Narufumi Kadomatsu, 'The Right to be Informed' (2002) 69 Hosei Kenkyu 265, 281-2 (emphasis in original).
} 
for the handling of information since the law was introduced may couple with bureaucracy training programs to bring about a significant longer-term behavioural change towards transparency, the Heisei reforms of themselves have proven a flawed attempt to achieve this new normative agenda thus far.

\section{Corporate governance reforms}

In the area of corporate governance, the Heisei reforms' attempts to reorient the emphasis from preserving stakeholder relationships to protecting shareholder interests demonstrate an attempt to significantly transform Japanese commercial society. Previously, Japan's normative agenda promoted a 'community firm' model of corporate governance that aimed primarily to serve their stakeholder base of employees, institutional investors and business partners rather than their shareholders. ${ }^{41}$ Owing to the social and political realities of the postwar economy that generated serious labour unrest at the time, corporations became convinced that strong labour-management relations and fixed, long-term employment ensured the firm's productivity. ${ }^{42}$ Moreover, to secure stability of their operations, firms offered their trading partners, and the Japanese banks that funded their corporate activities, substantial shareholdings as recognition of continuing business relationships. ${ }^{43}$ Coupled with Japanese commercial society's basic belief that supervision and management must be integrated to coordinate long-term growth strategies, ${ }^{44}$ this normative agenda fostered a longstanding system of internal corporate monitoring and weak shareholder position that reinforced managerial discretion in firms' operations. ${ }^{45}$ Here, the commercial norm was that monitoring was based on informal peer review and other internal social pressures. ${ }^{46}$ Whereas this 'traditional' corporate model was credited with Japan's prior economic success, ${ }^{47}$ it was later seen as a serious flaw that concealed corporate misdemeanours and undermined the efficiency of corporate activity when the Japanese economy collapsed. ${ }^{48}$ Prompted also by the increasing proportion of institutional shareholders with profit motives and

\footnotetext{
41 See e.g. Masahiro Okuno-Fujiwara, 'Japan's Present-Day Economic System: Its Structure and Potential for Reform' in Tetsuji Okazaki and Masahiro Okuno-Fujiwara (eds), The Japanese Economic System and Its Historical Origins (Oxford University Press, 1999) 266, 266.

42 John Buchanan and Simon Deakin, 'In the Shadow of Corporate Governance Reform: Change and Continuity in Managerial Practice at Listed Companies in Japan' in D. Hugh Whittaker and Simon Deakin (eds), Corporate Governance and Managerial Reform in Japan (Oxford University Press, 2009) 29, 32.

43 Simon Learmount, Corporate Governance: What Can Be Learned from Japan? (Oxford University Press, 2002) 56-7.

44 Buchanan and Deakin, above n 42, 32-33.

45 Ibid., 41-2; see e.g. Paul Sheard, 'Interlocking Shareholdings and Corporate Governance', in Masahiko Aoki and Ronald Dore (eds), The Japanese Firm: Sources of Competitive Strength (Oxford University Press, 1994) 310, 311; Buchanan and Deakin, above n 42, 49.

46 Ronald Dore, 'Deviant or Different? Corporate Governance in Japan and Germany' (2005) 13 Corporate Governance: An International Review 437, 441.

47 Buchanan and Deakin, above n 42, 32.

48 Ibid., 32-4.
} 
mounting shareholder activism, ${ }^{49}$ reforms to reshape the 'traditional' normative agenda have since turned to US models of corporate governance and sought to prioritise current shareholder interests in corporate transparency and efficiency instead. ${ }^{50}$ To this extent, the Heisei corporate governance reforms have attempted to significantly transform the normative agenda that has previously guided Japanese commercial society.

However, the extent to which Japanese commercial society's normative agenda has actually been reshaped through legal reform should not be overstated. Here, deliberations to strengthen external monitoring have confronted corporate Japan's longstanding stakeholder interests and commercial norms. ${ }^{51}$ These include the expectation for corporations to offer job security and the tacit understanding that managers remain in the best position to run the firm. ${ }^{52}$ Far from framing laws to modify longstanding corporate structures, the new reforms were conceived in a way that suited pre-existing commercial norms. The introduction of an optional 'companies with committees' system as a measure to enhance corporate transparency is illustrative here. While this granted external directors a stronger role in reviewing corporate finances, several reprieves including its optional application impede the extent to which corporate transparency and efficiency may be improved.$^{53}$ For instance, these external directors may also be officers of parent companies. ${ }^{54}$ Since these officers are linked to the firm through business interests and thus not truly independent, they may not provide an adequate check and balance on the firm's managerial discretion. ${ }^{55}$ In granting corporations significant latitude to continue prioritising stakeholder interests, ${ }^{56}$ the legal reforms remain ill-equipped to conceive a normative shift towards prioritising shareholder interests. Accordingly, rather than wholly adopting US models of corporate governance, Japanese laws have only adopted aspects that are reconcilable with existing socioeconomic structures. ${ }^{57}$ Therefore, it would

49 See e.g. Takaya Seki, 'Legal Reform and Shareholder Activism by Institutional Investors in Japan' (2005)

13 Corporate Governance: An International Review 377; Buchanan and Deakin, above n 42, 47.

50 See e.g. Christina L Ahmadjian, 'Changing Japanese Corporate Governance' in Ulrike Schaede and William Grimes (eds), Japan's Managed Globalization: Adapting to the Twenty-First Century (M E Sharpe, 2003) $215,218-22$.

51 See e.g. Takeshi Inagami and D. Hugh Whittaker, The New Community Firm: Employment, Governance and Management Reform in Japan (Cambridge University Press, 2005) 109-10; Buchanan and Deakin, above n $42,29,49$.

52 Buchanan and Deakin, above n 42, 60; see e.g. Ronald Dore, 'Insider Management and Board Reform: For Whose Benefit?' in Masahiko Aoki, Gregory Jackson and Hideaki Miyajima (eds), Corporate Governance in Japan: Institutional Change and Organizational Diversity (Oxford University Press, 2007) 370, 390.

53 See e.g. Buchanan and Deakin, above n 42, 36-8.

54 Buchanan and Deakin, above n 42, 37.

55 Ibid.

56 Ibid., 60.

57 See e.g. Masao Nakamura, 'Adoption and Policy Implications of Japan's New Corporate Governance Practices after the Reform' (2011) 28 Asia Pacific Journal of Management 187, 188. 
be misguided to conclude that corporate governance reforms have significantly transformed the normative agenda of Japanese commercial society from its predominant stakeholder protection emphasis.

Whether or not the Heisei reforms reflect a significant normative shift, it remains the case that behavioural change in corporate Japan has fallen short of the aspirations set by legal reform. Due to persisting convictions in the need to exclude external influence and to preserve the 'community firm', 58 most of corporate Japan's 'traditional' practices persist. ${ }^{59}$ As of 2008 , for instance, the Tokyo Stock Exchange reported that only 4.6 per cent of listed companies have implemented the 'company with committees' system. ${ }^{60}$ Even where change has occurred, it has been as much a natural response to current economic and social circumstances as a reaction to the legal reforms. Here, Buchanan and Deakin argue that corporate behaviour had started to shift in this direction even prior to the Heisei reforms by responding quickly to globalisation and the need to enhance their efficiency. ${ }^{61}$ Companies like Sony and Toyota had, for example, already started modifying their business structures in the early 1990s to clarify managerial responsibilities and speed up decision-making. ${ }^{62}$ Rather than shaping corporate behaviour, these trends reflect how corporate governance reforms have at least in part mirrored existing corporate practices. Accordingly, legal reforms have driven behavioural change in Japan's commercial society only to a minimal extent.

Nevertheless, by formalising a renewed normative agenda in a legal framework, Japan's corporate governance reforms have provided another basis upon which firms can mediate competing economic and social imperatives in their corporate structure to adapt to changing circumstances. On the economic front, corporate managers have increasingly recognised the benefits of enhancing international competitiveness by improving corporate transparency and efficiency. ${ }^{63}$ However, this has confronted enduring expectations across Japanese commercial society that 'managers should be left to manage' ${ }^{64}$ For example, despite the substantial returns that shareholders could expect if a takeover were permitted to proceed unimpeded, both shareholders and the Japanese courts have acquiesced in managerial decisions to establish anti-takeover defences

\footnotetext{
58 Buchanan and Deakin, above n 42, 60.

59 Ibid.; see also Inagami and Whittaker, above n 51, 109-10.

60 Buchanan and Deakin, above n 42, 38.

61 Ibid., 42-3.

62 Ibid., 35, 43.

63 Curtis J. Milhaupt, 'A Lost Decade for Japanese Corporate Governance Reform?: What Has Changed, What Hasn't, and Why' in Magnus Blomstrom and Sumner La Croix (eds), Institutional Change in Japan Routledge, 2006) 97, 106-7, 109-111.

64 Buchanan and Deakin, above n 42, 51.
} 
and protect stakeholders. ${ }^{65}$ On the social front, despite marginal changes to corporate employment conditions and national attitudes about the viability of the 'community firm', deep-seated expectations that corporations will offer long-term employment have persisted. ${ }^{66}$ Accordingly, while there have been mounting pressures to radically change a firm's formal structures to match 'global standards' of corporate transparency and efficiency, ${ }^{67}$ there has also been a need to preserve a large part of existing internal operations to fulfil other social and economic norms. ${ }^{68}$ Here, the optional 'company with committees' system and its several dispensations, for example, have allowed firms to alter corporate structures in a flexible manner that allows them precisely to achieve these twin goals. ${ }^{69}$ Therefore, by providing a formal basis upon which firms can mediate the conflicting dynamics that exist in Japanese commercial society, legal reforms have been a facilitating, albeit not a necessary or predominant, condition of behavioural change in corporate Japan.

\section{Gender equality reforms}

As for gender equality issues, the Heisei reforms demonstrate a progressive yet incremental reworking of Japanese society's social norms. Since feudal times, Confucian principles had been deeply imbued in Japan's political and social norms as their endorsement of hierarchical power relationships was a useful tool for regulating societal relations. ${ }^{70}$ Accordingly, the Japanese conceived gender divisions according to Confucian precepts, where women were more suited to the caregiver role in the household while men worked outside and provided for the family. ${ }^{71}$ Despite subsequently being granted gender equality under the postwar Japanese Constitution, ${ }^{72}$ the imposition of foreign standards confronted this persistent influence of Confucian principles on social attitudes and thus failed to take on legal significance. ${ }^{73}$ Courts also rejected the constitutional

65 Ibid., 55-6. See e.g. Bull-dog Sauce Case SCOJ 2007, No. 3 and Shu-Ching Chen, 'Japan High Court Keeps Bull-Dog Sauce From Steel Partners' Jaws', Forbes (Asia), 8 August 2007.

66 Inagami and Whittaker, above n 51, 109-10.

67 See e.g. Japan Corporate Governance Forum (JCGF), Corporate Governance Principles - A Japanese View (Interim Report) (1997); Ahmadjian, above n 50, 216, 222.

68 See e.g. Buchanan and Deakin, above n 42, 38-45.

69 Buchanan and Deakin, above $n$ 42, 38-42.

70 Scott North, 'Negotiating What's “Natural": Persistent Domestic Gender Role Inequality in Japan' (2009) 12(1) Social Science Japan Journal 23, 24-5; Kenneth L. Port and Gerald Paul McAlinn, 'Family Law', in Kenneth L. Port and Gerald Paul McAlinn (eds), Comparative Law: Law and the Legal Process in Japan (Carolina Academic Press, 2nd ed., 2003), 965.

71 Rebecca Ray, Janet Gornick and John Schmitt, 'Parental Leave Policies in 21 Countries: Assessing Generosity and Gender Equality' (Report, Center for Economic and Policy Research, 2008) 2; Kingston, Japan's Quiet Transformation, above n 4, 276; See e.g. Kimiko Tanaka, 'Surnames an Gender in Japan: Women's Challenges in Seeking Own Identity' (2012) 37 Journal of Family History 232.

72 See e.g. Art 14, 24, 44 of the Japanese Constitution, cited in Yasuo Takao, Reinventing Japan: From Merchant Nation to Civic Nation (Palgrave Macmillan, 2007) 136.

73 Carl Goodman, The Rule of Law in Japan: A Comparative Analysis (Kluwer Law, 2003) 92-103. 
norm of gender equality as 'ahead of the times' ${ }^{74}$ Following the Japanese economy's 'lost decade', however, political actors were able to reframe existing gender inequality from a characteristic that was associated with the 'virtues' of Confucian social order to one that impeded Japan's realisation of economic goals. ${ }^{75}$ Here, progressivist political actors were able to align their political agenda of increasing female participation in the workforce with the pressing economic imperative of enhancing the economy's productivity in an ageing society. ${ }^{76}$ By ushering in a different understanding of gender roles within the government, these favourable economic circumstances and political opportunism triggered an 'exten[sion of] unexpected rights to women ... within a short period of time' ${ }^{77}$ Reforms such as the Basic Law for a Gender-Equal Society have not only prescribed against stereotyped gender divisions but also required the state to create institutional mechanisms promoting equal gender participation at all levels of society. ${ }^{78}$ For example, while women were seen as the primary providers of elderly care under the patriarchal style of government policy before, the mandatory 'Long-Term Care Insurance' policy transferred a substantial part of these household responsibilities to the state by providing caregiving benefits to the aged..$^{79}$ This demonstrates a conscious shift in Japan's legal framework to remove structural impediments to female participation outside the home. ${ }^{80}$ To be sure, some pre-existing legal structures remain untouched. For example, Japan's family tax policy continues to incentivise non-participation of females in the permanent workforce ${ }^{81}$ Nevertheless, in seeking to weaken impediments to achieving gender equality in existing policy and social norms for the first time, the Heisei reforms have signalled an ambitious but gradual shift from one that curtails female participation outside the household to one that promotes it.

However, while the principles of gender equality have been endorsed by the new laws, their incorporation into practice has not been fully realised. Although gender equality policies have been driven by stronger political will and supported by 'an unprecedented number of policy changes and [legislative] reforms at the national level', ${ }^{82}$ their development has merely demonstrated the capacity of sectional interests to achieve specific policy outputs through strategic political manoeuvring. Indeed, while then Prime Minister Hashimoto Ryutaro was able

74 Ibid., 98

75 Mari Osawa, 'Government Approaches to Gender Equality in the Mid-1990s' (2000) 3 Social Science Japan Journal 3, 3-5.

76 Ibid.

77 Takao, above n 72, 144.

78 See e.g. Takao, above n 72, 142-3.

79 Ibid., 141.

80 See e.g. Takao, above n 72, 141-2.

81 Rebecca C. Tompkins, 'Working for Change: Gender Inequality in the Labor Force in Japan, South Korea,

and Taiwan' (Working Paper, International Studies Program - Trinity College, 2 May 2011) 16-7.

82 Takao, above n 72, 135. 
to position gender equality among the top priorities of Japan's political agenda by justifying it as an economic necessity, there was no indication at the time that this progressive orientation represented the views of the LDP government or of Japanese society as a whole. ${ }^{83}$ While there had been increasing activism by women's political groups that challenged male-dominated hierarchies of power, ${ }^{84}$ there remained a need for these separate clusters of sectional interests to engage with wider social attitudes in Japan. ${ }^{85}$ Moreover, a combination of longstanding inclinations to preserve male supremacy among top-level officers in a wide variety of Japanese organisations ${ }^{86}$ and existing disincentives for women to participate outside the household have contributed to inertia in behavioural change. ${ }^{87}$ On the political front, despite recognising the need for increased female participation across Japanese society, North highlights that current government deliberations about breaking down gender stereotypes centre around 'enabl[ing] women to work and care rather than helping men to care' ${ }^{88}$ In the corporate sphere, company policies restricting women's hours of employment and availability of parental leave for men continue to support the defined gender roles in family work under Confucian principles. ${ }^{89}$ Therefore, absent any indications of substantial change in other policies and practices following the Heisei reforms, to equate the effective capture of political decisionmaking by particular interest groups with wider behavioural change of Japanese society would be misguided.

\section{Implications}

By evaluating the processes of legal change with the aid of systems theory, it becomes evident that the transformative power of the Heisei reforms lies not in the achievement of outcomes but in expediting the processes of re-evaluating societal norms. To bring about successful legal change, the nature of legal reforms must be tailored to a society's idiosyncrasies. In a society governed by informal norms rather than by the 'rule of law' such as Japan, ${ }^{90}$ legal reforms

\footnotetext{
83 Osawa, above n 75, 3-5.

84 See e.g. Taimie L. Bryant, 'For the Sake of the Country, For the Sake of the Family: The Oppressive Impact of Family Registration on Women and Minorities in Japan', in Kenneth L. Port and Gerald Paul McAlinn (eds), Comparative Law: Law and the Legal Process in Japan (Carolina Academic Press, 2nd ed., 2003) 968, 969; North, above n 70, 32.

85 See e.g. Elisabeth Porter, “'Engendering the State: The International Diffusion of Women's Human Rights" - Book Review' (2011) 17(1) Social Identities, 163, 163.

86 See e.g. Tompkins, above n 81, 5-10; North, above n 70, 25; Takao, above n 72, 142.

87 Osawa, above n 75, 18.

88 North, above $n$ 70, 25

89 Ibid., 24-5. See also Fang Lee Cooke, 'Women's Participation in Employment in Asia: A Comparative Analysis of China, India, Japan and South Korea' (2010) 21 The International Journal of Human Resource Management 2249, 2256-8.

90 Goodman, above n 73, 3; Tom Ginsburg, 'Japanese Legal Reform in Historical Perspective' (Draft, University of Illinois College of Law, 28 October 2002) 2.
} 
must start by recognising the virtues of legal instruments as a symbolic tool for furthering discourse and thus re-evaluating existing societal norms rather than necessarily of themselves bringing about behavioural change.

As demonstrated in the three case studies above, by harnessing concepts of government transparency, shareholder interests and gender equality, the Heisei reform processes have provided a renewed site of negotiation between old and new interests. While this involved a rejuvenated compromise between pre-existing stakeholder and new shareholder interests through corporate governance reforms, it extended to reinvigorated citizen-state and gender relations in the cases of information disclosure and gender equality policies respectively. In this way, the Heisei reforms have effectively captured the nature of law and society's interaction in Japan, where legal devices must go through the process of influencing societal discourse and, by extension, their underlying norms in order to establish the foundations of structural change. Despite the fitful and ambiguous pathways that normative and behavioural change have taken in all these instances of reform, they merely reflect Japanese society's process of mediating tensions underlying political, economic and social norms in reaching a new equilibrium. Therefore, by strategically employing legal devices not merely for their instrumental value in achieving specific reform objectives in the short term but as a means to frame political, economic and social discourse and gradually influence their underlying norms, the Heisei reforms have sought to squarely engage with the relationship between Japanese law and society and thus have effectively established the foundations for longerterm transformative change.

\section{Conclusion}

By applying a systems theory approach to the case studies of information disclosure, corporate governance and gender equality, this paper argues that the Heisei reforms have reshaped political, economic and social dimensions of Japanese society in ways that other approaches may have overlooked. While the Heisei reforms have not instigated significant societal transformation in Japan as an instrumental device, they have nevertheless fulfilled an important symbolic purpose by starting to reshape societal discourse and its underlying norms in achieving long-term change. Altogether, an evaluation of the Heisei reforms presents a cautionary tale which calls into question how scholars understand the relationship between law and society across different contexts, and which rejects the simplistic assumption that law is purely an instrumental device to achieve societal reform in every circumstance. 


\section{Bibliography}

\section{Articles/Books/Reports}

Ahmadjian, Christina L., 'Changing Japanese Corporate Governance' in Ulrike Schaede and William Grimes (eds), Japan's Managed Globalization: Adapting to the Twenty-First Century (M.E. Sharpe, 2003) 215.

Anderson, Kent and Trevor Ryan, 'Japan: The Importance and Evolution of Legal Institutions at the Turn of the Century' in E. Ann Black and Gary F Bell (eds), Law and Legal Institutions of Asia (Cambridge University Press, 2011) 120 .

Beck, Anthony, 'Is Law an Autopoietic System?' (1994) 14 Oxford Journal of Legal Studies 401.

Boling, David, 'Access to Government-Held Information in Japan: Citizens' "Right to Know" Bows to the Bureaucracy' (1998) 34 Stanford Journal of International Law 1.

Bryant, Taimie L., 'For the Sake of the Country, For the Sake of the Family: The Oppressive Impact of Family Registration on Women and Minorities in Japan', in Kenneth L. Port and Gerald Paul McAlinn (eds), Comparative Law: Law and the Legal Process in Japan (Carolina Academic Press, 2nd ed., 2003) 968.

Buchanan, John and Simon Deakin, 'In the Shadow of Corporate Governance Reform: Change and Continuity in Managerial Practice at Listed Companies in Japan' in D. Hugh Whittaker and Simon Deakin (eds), Corporate Governance and Managerial Reform in Japan (Oxford University Press, 2009) 29.

Chen, Shu-Ching, 'Japan High Court Keeps Bull-Dog Sauce From Steel Partners' Jaws', Forbes (Asia), 8 August 2007.

Cooke, Fang Lee, 'Women's Participation in Employment in Asia: A Comparative Analysis of China, India, Japan and South Korea' (2010) 21 The International Journal of Human Resource Management 2249.

Dore, Ronald, 'Deviant or Different? Corporate Governance in Japan and Germany' (2005) 13 Corporate Governance: An International Review 437.

Dore, Ronald, 'Insider Management and Board Reform: For Whose Benefit?' in Masahiko Aoki, Gregory Jackson and Hideaki Miyajima (eds), Corporate Governance in Japan: Institutional Change and Organizational Diversity (Oxford University Press, 2007) 370. 
Gillespie, John, 'Towards a Discursive Analysis of Legal Transfers into Developing East Asia' (2008) 40 International Law and Politics 657.

Ginsburg, Tom, 'Japanese Legal Reform in Historical Perspective' (Draft, University of Illinois College of Law, 28 October 2002).

Goodman, Carl F., The Rule of Law in Japan: A Comparative Analysis (Kluwer Law, 2003).

Haley, John Owen, Authority without Power (Oxford University Press, 1991).

Haley, John O., 'Heisei Renewal or Heisei Transformation: Are Legal Reforms Really Changing Japan?' (Working Paper No. 05-10-02, The Washington University School of Law, October 2002).

Inagami, Takeshi and D. Hugh Whittaker, The New Community Firm: Employment, Governance and Management Reform in Japan (Cambridge University Press, 2005).

Japan Corporate Governance Forum (JCGF), Corporate Governance Principles A Japanese View (Interim Report) (Japan Corporate Governance Forum, 1997).

Kadomatsu, Narifumi, 'Accountability of Administration in Japan after the Mid1990s' (2011) 31 Journal of Japanese Law 5.

Kadomatsu, Narufumi, 'The Right to be Informed' (2002) 69 Hosei Kenkyu 265.

King, Michael, 'The "Truth" About Autopoiesis' (1993) 20(2) Journal of Law and Society 220.

Kingston, Jeff, Japan's Quiet Transformation (Routledge Curzon, 2004).

Kingston, Jeff, Contemporary Japan: History, Politics, and Social Change since the 1980s (Wiley Blackwell, 2nd ed., 2013).

Kozuka, Souichirou, 'Conclusions: Japan's Largest Companies, Then and Now' in Luke Nottage, Leon Wolff and Kent Anderson (eds), Corporate Governance in the 21st Century (Edward Elgar, 2008) 228.

Law, David S, 'Why Has Judicial Review Failed in Japan?' (2011) 88 Washington University Law Review 1425.

Learmount, Simon, Corporate Governance: What Can Be Learned from Japan? (Oxford University Press, 2002).

Luhmann, Niklas, 'The Unity of the Legal System' in Gunther Teubner (ed), Autopoietic Law: A New Approach to Law and Society (De Gruyter, 1988) 12. 
McAlinn, Gerald Paul, 'Law Reform in Japan,: Building Infrastructure for the 21 st Century' in Kenneth L Port and Gerald Paul McAlinn (eds), Comparative Law: Law and the Legal Process in Japan (Carolina Academic Press, 2nd ed., 2003) 113.

Milhaupt, Curtis J., 'A Lost Decade for Japanese Corporate Governance Reform?: What Has Changed, What Hasn't, and Why' in Magnus Blomstrom and Sumner La Croix (eds), Institutional Change in Japan (Routledge, 2006) 97.

Nakamura, Masao, 'Adoption and Policy Implications of Japan's New Corporate Governance Practices after the Reform' (2011) 28 Asia Pacific Journal of Management 187.

North, Scott, 'Negotiating What's "Natural": Persistent Domestic Gender Role Inequality in Japan' (2009) 12(1) Social Science Japan Journal 23.

Okuno-Fujiwara, Masahiro, 'Japan's Present-Day Economic System: Its Structure and Potential for Reform' in Tetsuji Okazaki and Masahiro OkunoFujiwara (eds), The Japanese Economic System and Its Historical Origins (Oxford University Press, 1999) 266.

Osawa, Mari, 'Government Approaches to Gender Equality in the Mid-1990s' (2000) 3 Social Science Japan Journal 3.

Port, Kenneth L and Gerald Paul McAlinn, 'Family Law', in Kenneth L. Port and Gerald Paul McAlinn (eds), Comparative Law: Law and the Legal Process in Japan (Carolina Academic Press, 2nd ed., 2003) 965.

Porter, Elisabeth, “"Engendering the State: The International Diffusion of Women's Human Rights" - Book Review' (2011) 17(1) Social Identities 163.

Ray, Rebecca, Janet Gornick and John Schmitt, 'Parental Leave Policies in 21 Countries: Assessing Generosity and Gender Equality' (Report, Center for Economic and Policy Research, 2008) .

Repeta, Lawrence, 'Local Government Disclosure Systems in Japan' (Working Paper No. 16, The National Bureau of Asian Research, October 1999) .

Repeta, Lawrence, 'Special Note: "Freedom" of Information?' in Kenneth L. Port and Gerald Paul McAlinn (eds), Comparative Law: Law and the Legal Process in Japan (Carolina Academic Press, 2nd ed., 2003) 1021.

Seki, Takaya, 'Legal Reform and Shareholder Activism by Institutional Investors in Japan' (2005) 13 Corporate Governance: An International Review 377. 
Sheard, Paul, 'Interlocking Shareholdings and Corporate Governance', in Masahiko Aoki and Ronald Dore (eds), The Japanese Firm: Sources of Competitive Strength (Oxford University Press, 1994) 310.

Takao, Yasuo, Reinventing Japan: From Merchant Nation to Civic Nation (Palgrave Macmillan, 2007) .

Tanaka, Kimiko, 'Surnames an Gender in Japan: Women's Challenges in Seeking Own Identity' (2012) 37 Journal of Family History 232.

Tanase, Takao, Community and the Law: A Critical Reassessment of American Liberalism and Japanese Modernity (Edward Elgar, 2010).

Tompkins, Rebecca C., 'Working for Change: Gender Inequality in the Labor Force in Japan, South Korea, and Taiwan' (Working Paper, International Studies Program - Trinity College, 2 May 2011).

Uga, Katsuya, 'Development of the Concepts of Transparency, and Accountability in Japanese Administrative Law' in Daniel H. Foote (ed), Law in Japan: A Turning Point (University of Washington Press, 2007) 276.

\section{Cases}

Bull-dog Sauce Case SCOJ 2007, No. 3. 
This text is taken from The ANU Undergraduate Research Journal, Volume Six, 2014, edited by Jonathon Zapasnik and Alexandra Hogan, published 2015 by ANU eView, The Australian National University, Canberra, Australia. 